\title{
Measurement of Complex Formation Process of Nickel (II) with Freshwater Fulvic Acids Using the Solubility Method
}

\author{
T. Makharadze, G. Makharadze* \\ Department of Chemistry, Ivane Javakhishvili Tbilisi State University, Tbilisi, Georgia \\ E-mail: gogimakharadze@yahoo.com
}

Received: 13 April 2021; Revised: 10 July 2021; Accepted: 10 July 2021

\begin{abstract}
The complex formation process between Ni(II) and fulvic acids has been studied through the solubility method at $\mathrm{pH}=9.0$. The old suspension of $\mathrm{Ni}(\mathrm{OH})_{2}$ is used as a solid phase. Fulvic acids are isolated from Paravani lake by the adsorption-chromatographic method. The activated charcoal is used as a sorbent. The concentration of fulvic acids in model solutions changes from $1.1 \times 10^{-5} \mathrm{~mol} / \mathrm{L}$ to $4.4 \times 10^{-5} \mathrm{~mol} / \mathrm{L}$. The value of molar mass of fulvic acids at $\mathrm{pH}=9.0$ was taken into consideration for the calculation of molar concentrations of fulvic acids. Before adding the ligand the initial concentration of nickel was $3.8 \times 10^{-6} \mathrm{~mol} / \mathrm{L}$. This article has shown that, during complex formation process every 0.25 part of an associate of fulvic acids $(\mathrm{Mw}=7610)$, inculcates into nickel's inner coordination sphere as an integral ligand, so it may be assumed, that the average molecular weight of the associate of fulvic acids which takes part in complex formation process equals to 1903. This part of the associate of fulvic acids was conventionally called the "active associate". The average molecular weight of the "active associate" was used for determining the concentration of free ligand and average stability constant (1:1), which equals to $\beta=1.07 \times 10^{7}(\lg \beta=$
\end{abstract} 7.03)

Keywords: fulvic acids, nickel dihydroxy fulvate complex, average stability constant, active associate

\section{Introduction}

Macromolecular Organic Substances-Fulvic Acids (FA) are natural organic complexing agents, found in the environment that originates from chemically and microbially modified plant and animal matter. They are the major organic matter of natural waters. FA concentrations ranges from less than $1 \mathrm{mg} / \mathrm{L}$ to more than $100 \mathrm{mg} / \mathrm{L}{ }^{1-6} \mathrm{The}$ chemical structure of FA has not been finalized yet. The elemental composition (\%) of FA is isolated from natural waters changes C 46.7 59.7; H 4.1 5.5; O 31.8 49.7; N 0.74 3.3 and S 0.4 1.7. , $7-10^{2}$

FA form stable complexes with heavy metals and radionuclides ${ }^{1,11-21}$ and stipulate migration forms thereof in natural waters and soils. ${ }^{1,3,22-27}$ Therefore, FA may affect the transport, accumulation, bioavailability, and toxicity of metals in the environment.

The carboxylic and phenolic groups of FA take an active part in complex formation and sorption processes, proceeding in natural waters, bottom sediments and soils. ${ }^{1,28-31} \mathrm{pK}_{\mathrm{H}, \mathrm{COOH}}$ changes from 4.1 to 4.9 , and $\mathrm{pK}_{\mathrm{H}, \mathrm{Ph}-\mathrm{OH}}$ (the dissociation constant of phenolic group of fulvic acids) changes from 9.3 to $10.6^{1,4,5,29,32}$ The participation of carboxylic

Copyright (C2021 G. Makharadze, et al.

DOI: https://doi.org/10.37256/fce.222021870

This is an open-access article distributed under a CC BY license

(Creative Commons Attribution 4.0 International License)

https://creativecommons.org/licenses/by/4.0/ 
or phenol hydroxide groups depends not only on the value of $\mathrm{pH}$ (which determines the dissociation degree of carboxylic and phenol groups), also on the nature of metals. For example $\mathrm{Al}, \mathrm{Pb}, \mathrm{Hg}$, and $\mathrm{Cr}$, which are preferentially bound to the phenolic sites of the fulvic ligand; $\mathrm{Ca}, \mathrm{Mg}, \mathrm{Cd}, \mathrm{Fe}(\mathrm{II})$, and $\mathrm{Mn}$, which display a greater effective affinity for carboxylic sites, in contrast to what would be expected from their individual complexation parameters; and Fe(III), $\mathrm{Cu}, \mathrm{Zn}$, and $\mathrm{Ni}$, for which phenolic and carboxylic distributions are overlapped. ${ }^{29}$

In spite of researches, the experimental data on stability constants $(\beta)$ of complex compounds of FA with nickel (as in the case of other metals) is heterogeneous and it differs in several lines from each other. ${ }^{33-40}$ This condition is mainly stipulated by ignoring the average molecular weight $(\mathrm{Mw})$ of the associates of FA, which value in its turn depends on the value of $\mathrm{pH}$ and finally causes the wrong results. Therefore, it's difficult to investigate complex formation processes, taking place in natural waters, identify migration forms of nickel and evaluate and assess chemical-ecological condition of natural waters.

Objective of the work is to investigate complex formation process between the pure samples of FA, isolated from natural water and to calculate the average stability constant of nickel fulvate complex. Complex formation process has been studied at $\mathrm{pH}=9.0$ by the solubility method. While practically using this method, in case of choosing correctly the solid phase, polynuclear hydrolysis is impossible and is easy for the determining the exact composition and stability constants of complex. The old suspension of $\mathrm{Ni}(\mathrm{OH})_{2}$ was used as a solid phase.

\section{Materials and methods}

For obtaining pure samples of FA, after filtration through membrane filters $(0.45 \mu \mathrm{m}$ pore size $)$, the water of Paravani lake was concentrated by the frozen method. The concentrated water samples were acidified with $6 \mathrm{M} \mathrm{HCl}$ to $\mathrm{pH} 2$ and was put for 2 hours on water bath at $60^{\circ} \mathrm{C}$ for coagulation of humin acids. Then the solution was centrifuged for $10 \mathrm{~min}$ at $8000 \mathrm{rpm}$ (Centrifuge T-23). The adsorption-chromatographic method was used for isolating FA from centrifugate. Charcoal was used as a sorbent. Desorption of amino acids and carbohydrates was performed by means of $0.1 \mathrm{M} \mathrm{HCl} .90 \%$ acetone water solution was used for desorbing polyphenols. The elution of the fraction of FA was performed with $0.1 \mathrm{~N}$ sodium hydroxide solution. ${ }^{1,41}$ Obtained alkalic solution of FA, for the purification was passed through a cation-exchanger (KU-2-8). For the determination of the concentration of FA in the obtained solution was used gravimetric method, the part of the solution was dried under vacuum until the constant weight was obtained. Elemental composition of standard samples of FA was isolated from natural waters and average value of dissociation constants respectively equals to C- $53.75 \%, \mathrm{H}-4.29 \%$; O- $40.48 \%, \mathrm{~N}-0.68 \%, \mathrm{~S}-0.50 \%$; $\mathrm{P}-0.01 \%$; ashing $0.35 ; \mathrm{pK}_{\mathrm{H}, \mathrm{CoOH}}$ $=4.37, \mathrm{pK}_{\mathrm{H}, \mathrm{Ph}-\mathrm{OH}}=10.4$. Then, model solutions of FA were prepared. The solution of fulvate complexes was obtained by the solubility method. $0.1 \mathrm{ml}$ suspension of old nickel hydroxide and the increasing quantity of standard solution of FA were placed in $15 \mathrm{ml}$ capacity fluoroplastic cylinders. The concentration of FA in model solutions changes from 1.1 $\times 10^{-5} \mathrm{~mol} / \mathrm{L}$ to $4.4 \times 10^{-5} \mathrm{~mol} / \mathrm{L}$. Before adding ligand the initial concentration of nickel was $3.8 \times 10^{-6} \mathrm{~mol} / \mathrm{L}$. $\mathrm{pH}=9.0$, ionic strength $\mu=0.01\left(\mathrm{KNO}_{3}\right), v=10 \mathrm{ml}$. The concentration of hydrogen ions was regulated by the addition of 0.01 $\mathrm{M} \mathrm{HNO}_{3}$ acid or $0.01 \mathrm{M} \mathrm{NaOH}$ ( $\mathrm{pH}$ meter $\mathrm{pH}$ 2006). Then, it was stirred in a mechanical mixer for 100 hours, until the balance was achieved and then suspension was filtered through the membrane filters ( $0.45 \mu \mathrm{m}$ pore size). In filtrates, the concentration of nickel was measured by atomic absorption spectrophotometer (Perkin Elmer 200).

\section{Results and discussion}

The data has shown that in line with the increasing of concentration of FA in solution, the concentration of nickel increases for several times as well due to the formation of fulvate complex (Table 1). During the calculation of molar concentrations of FA, the fact that they (FA) form associates in water solutions was taken into consideration. While the investigation of water solutions of FA by the gel chromatographic method was established, that in the interval $\mathrm{pH} 4 \sim 11$, there is a line dependence of the average molecular weight $\mathrm{FA}(\mathrm{Mw})$ and the value of $\mathrm{pH}$, which is expressed in the following way: $\mathrm{Mw}=1350 \mathrm{pH}-4540 .{ }^{1}$ At $\mathrm{pH}=9, \mathrm{Mw}(\mathrm{FA})=7610$.

In the diluted water solutions, the forms of nickel $\left(\beta_{\mathrm{NiOH}^{+}}=5.5 \times 10^{4}, \beta_{\mathrm{Ni}(\mathrm{OH})_{2}}{ }^{2}=5.4 \times 10^{14}\right)^{42}$ were calculated 
through the following formulas (1-3):

$$
\begin{gathered}
\mathrm{Ni}^{2+} \%=100 /\left(1+\beta_{1.1}\left[\mathrm{OH}^{-}\right]+\beta_{1.2}\left[\mathrm{OH}^{-}\right]^{2}\right) \\
\mathrm{NiOH}^{+} \%=\beta_{1.1}\left[\mathrm{OH}^{-}\right] 100 /\left(1+\beta_{1.1}\left[\mathrm{OH}^{-}\right]+\beta_{1.2}\left[\mathrm{OH}^{-}\right]\right) \\
\mathrm{Ni}(\mathrm{OH})_{2}{ }^{0} \%=\beta_{1.2}\left[\mathrm{OH}^{-}\right]^{2} 100 /\left(1+\beta_{1.1}\left[\mathrm{OH}^{-}\right]+\beta_{1.2}\left[\mathrm{OH}^{-}\right]^{2}\right)
\end{gathered}
$$

Where $\beta_{1.1}$ - the stability constant of $\mathrm{MeOH}^{+}, \beta_{1.2}$-the stability constant of $\mathrm{Me}(\mathrm{OH})_{2}$.

As the results show, nickel dihydroxy complex $\mathrm{Ni}(\mathrm{OH})_{2}{ }^{0}$ is the dominant form at $\mathrm{pH}=9.0$.

The reaction between nickel dihydroxy complex and the anions of FA may be written in the following way:

$$
\begin{gathered}
\mathrm{Ni}(\mathrm{OH})_{2}{ }^{0}+m \mathrm{FA}=\mathrm{Ni}(\mathrm{OH})_{2}(\mathrm{FA})_{\mathrm{m}} \\
\beta=\left[\mathrm{Ni}(\mathrm{OH})_{2} \mathrm{FA}_{\mathrm{m}}\right] /\left\{\left[\mathrm{Ni}(\mathrm{OH})_{2}{ }^{0}\right][\mathrm{FA}]^{\mathrm{m}}\right\}
\end{gathered}
$$

In solution, the concentration of nickel dihydroxy fulvate complex equals to the difference between final [Ni(II) $\left.)_{\text {total }}\right]$ and initial $\left[\mathrm{Ni}(\mathrm{II})_{\text {free }}\right.$ ] concentrations of nickel received after formation of complex:

$$
\left[\mathrm{Ni}(\mathrm{OH})_{2} \mathrm{FA}_{\mathrm{m}}\right]=\left[\mathrm{Ni}(\mathrm{II})_{\text {total }}-\mathrm{Ni}(\mathrm{II})_{\text {free }}\right] \text { and }\left[\mathrm{Ni}(\mathrm{OH})_{2}{ }^{0}\right]=\left[\mathrm{Ni}(\mathrm{II})_{\text {free }}\right]
$$

Put these values in (5)

$$
\beta=\left[\mathrm{Ni}(\mathrm{II})_{\text {total }}-\mathrm{Ni}(\mathrm{II})_{\text {free }}\right] /\left\{\left[\mathrm{Ni}(\mathrm{II})_{\text {free }}\right][\mathrm{FA}]^{\mathrm{m}}\right\}
$$

From (7) equation

$$
\beta\left[\mathrm{Ni}(\mathrm{II})_{\text {free }}\right]=\left[\mathrm{Ni}(\mathrm{II})_{\text {total }}-\mathrm{Ni}(\mathrm{II})_{\text {free }}\right] /[\mathrm{FA}]^{\mathrm{m}}
$$

At the fixed $\mathrm{pH}$, the left part of the equation (8) is a permanent value and we mark it as $K^{\prime}$.

$$
K^{\prime}=\left[\mathrm{Ni}(\mathrm{II})_{\text {total }}-\mathrm{Ni}(\mathrm{II})_{\text {free }}\right] /[\mathrm{FA}]^{\mathrm{m}}
$$

The logarithm of this equation (9) is:

$$
\lg K^{\prime}=\lg \left[\mathrm{Ni}(\mathrm{II})_{\text {total }}-\mathrm{Ni}(\mathrm{II})_{\text {free }}\right]-\operatorname{mlg}[\mathrm{FA}]
$$

The numeral value $(\mathrm{m})$ of the stoichiometric coefficient or the number of ligands in the inner coordination sphere of complex equals to tangent of tilt angle of straight line built in coordinates

$$
\lg \left[\mathrm{Ni}(\mathrm{II})_{\text {total }}-\mathrm{Ni}(\mathrm{II})_{\text {free }}\right]-\lg \left[\mathrm{FA}_{\text {total }}\right]
$$

For the calculation of the exact value of tangents tilt angle of straight line, was used the least square method:

$$
\mathrm{m}=\operatorname{tg} \alpha=\left(\mathrm{n} \Sigma \mathrm{x}_{\mathrm{i}} \mathrm{y}_{\mathrm{i}}-\Sigma \mathrm{x}_{\mathrm{i}} \Sigma \mathrm{y}_{\mathrm{i}}\right) /\left(\mathrm{n} \Sigma \mathrm{x}_{\mathrm{i}}^{2}-\left(\Sigma \mathrm{x}_{\mathrm{i}}\right)^{2}\right)
$$

where 


$$
\mathrm{x}_{\mathrm{i}}=\lg \left[\mathrm{FA}_{\text {total }}\right] \text { and } \mathrm{y}_{\mathrm{i}}=\lg \left[\mathrm{Ni}(\mathrm{II})_{\text {total }}-\mathrm{Ni}(\mathrm{II})_{\text {free }}\right]
$$

After the calculation, was obtained the numeral value of $\mathrm{m}(\mathrm{Mw}(\mathrm{FA})=7610)$ which equal to 0.98 (Table 1-2), most likely can be said that the complex obtained at $\mathrm{pH}=9$ in the system $\mathrm{Ni}(\mathrm{OH})_{2}$ (solid)-Ni(II)(solution)-FA- $\mathrm{H}_{2} \mathrm{O}$ is the nickel dihydroxy fulvate, with the structure 1:1.

So the complex formation reaction $(\mathrm{pH}=9.0)$ may be written:

$$
\mathrm{Ni}(\mathrm{OH})_{2}{ }^{0}+\mathrm{FA}=\mathrm{Ni}(\mathrm{OH})_{2} \mathrm{FA}
$$

Therefore, the formula for the stability constant can be expressed in the following way:

$$
\beta=\left[\mathrm{Ni}(\mathrm{OH})_{2} \mathrm{FA}\right] /\left\{\left[\mathrm{Ni}(\mathrm{II})_{\text {free }}\right][\mathrm{FA}]\right\}=\left[\mathrm{Ni}(\mathrm{II})_{\text {total }}-\mathrm{Ni}(\mathrm{II})_{\text {free }}\right] /\left\{\left[\mathrm{Ni}(\mathrm{II})_{\text {free }}\right][\mathrm{FA}]\right\} .
$$

Table 1. The dependence of the solubility of nickel hydroxide on the concentration of FA

\begin{tabular}{|c|c|c|c|c|c|}
\hline \multicolumn{3}{|c|}{$\mathrm{Mol} / \mathrm{L}$} & \multirow{2}{*}[\mathrm{Ni}_{\text{total}}]{$:\left[\mathrm{FA}_{\text {total }}\right]$} & \multirow{2}{*}{$\lg \left[\mathrm{FA}_{\text {total }}\right]$} & \multirow{2}{*}{$\lg \left[\mathrm{Ni}(\mathrm{OH})_{2} \mathrm{FA}\right]$} \\
\hline$\left[\mathrm{FA}_{\text {total }}\right]$ & {$\left[\mathrm{Ni}_{\text {total }}\right]$} & {$\left[\mathrm{Ni}(\mathrm{OH})_{2} \mathrm{FA}\right]$} & & & \\
\hline $1.11 \times 10^{-5}$ & $4.64 \times 10^{-5}$ & $4.26 \times 10^{-5}$ & $1: 0.23$ & -4.9547 & -4.3706 \\
\hline $1.66 \times 0^{-5}$ & $6.64 \times 10^{-5}$ & $6.26 \times 10^{-5}$ & $1: 0.25$ & -4.7799 & -4.2034 \\
\hline $2.22 \times 10^{-5}$ & $9.00 \times 10^{-5}$ & $8.62 \times 10^{-5}$ & $1: 0.25$ & -4.6536 & -4.0645 \\
\hline $2.77 \times 10^{-5}$ & $11.08 \times 10^{-5}$ & $10.62 \times 10^{-5}$ & $1: 0.25$ & -4.5575 & -3.9739 \\
\hline $3.33 \times 10^{-5}$ & $12.40 \times 10^{-5}$ & $12.02 \times 10^{-5}$ & $1: 0.27$ & -4.4775 & -3.9201 \\
\hline $3.88 \times 10^{-5}$ & $15.68 \times 10^{-5}$ & $15.30 \times 10^{-5}$ & $1: 0.25$ & -4.4112 & -3.8153 \\
\hline $4.44 \times 10^{-5}$ & $17.60 \times 10^{-5}$ & $17.22 \times 10^{-5}$ & $1: 0.25$ & -4.3526 & -3.7640 \\
\hline
\end{tabular}
and the necessary data for the determination the composition of nickel Dihydroxy fulvate complexes $\mathrm{pH}=9.0$; $\mathrm{Mw}(\mathrm{FA})=7610 ;\left[\mathrm{Ni}(\mathrm{II})_{\text {free }}\right]=3.8 \times 10^{-6} \mathrm{~mol} / \mathrm{L}$

Table 2. The calculation of the composition of nickel fulvate dihydroxy complex by the least square method, $\mathrm{Mw}(\mathrm{FA})=7610 ; \mathrm{pH}=9.0 . \mathrm{X}_{\mathrm{i}}=\lg \left[\mathrm{FA}_{\text {total }}\right], \mathrm{Y}_{\mathrm{i}}=\lg \left[\mathrm{NiFA}_{\mathrm{m}}\right]$

\begin{tabular}{cccc}
\hline$X_{i}$ & $Y_{i}$ & $X_{i} Y_{i}$ & $X_{i}^{2}$ \\
\hline-4.9547 & -4.3706 & 21.6550 & 24.5490 \\
-4.7799 & -4.2034 & 20.0918 & 22.8474 \\
-4.6536 & -4.0645 & 18.9145 & 21.6560 \\
-4.5575 & -3.9739 & 18.1110 & 20.7708 \\
-4.4775 & -3.9201 & 17.5522 & 20.0480 \\
-4.4112 & -3.8153 & 16.8300 & 19.4587 \\
-4.3526 & -3.7640 & 16.3832 & 18.9451 \\
\hline
\end{tabular}

$\sum \mathrm{X}_{\mathrm{i}}=-32.187 ;\left(\sum \mathrm{X}_{\mathrm{i}}\right)^{2}=1036.0029 ; \sum \mathrm{Y}_{\mathrm{i}}=-28.1118 ; \sum \mathrm{X}_{\mathrm{i}}^{2}=148.275 ; \sum \mathrm{X}_{\mathrm{i}} \mathrm{Y}_{\mathrm{i}}=129.5377 ; \mathrm{m}=0.98$

The complexation of FA to metal ions cannot be described in strict frames because of the ill-defined nature of FA in contrast to the complexation of single ligands. So in order to make it succeed the calculation of stability constants of fulvate complexes, it is necessary to make some assumptions. 
Table 3. The necessary data for the calculation of conditional stability constants of nickel fulvate complex by the leden method, $\mathrm{pH}=9.0 ; \mathrm{Mw}(\mathrm{FA})=1903,\left[\mathrm{Ni}(\mathrm{II})_{\text {free }}\right]=3.8 \times 10^{-6} \mathrm{~mol} / \mathrm{L} ; \mathrm{F}(\mathrm{FA})=\left[\mathrm{Ni}(\mathrm{OH})_{2} \mathrm{FA}\right] /\left(\left[\mathrm{Ni}(\mathrm{II})_{\text {free }}\right]\left[\mathrm{FA}_{\text {free }}\right]\right)$; $\left[\mathrm{FA}_{\text {free }}\right]=\left[\mathrm{FA}_{\text {total }}\right]-\left[\mathrm{Ni}(\mathrm{OH})_{2} \mathrm{FA}\right] ;\left[\mathrm{Ni}(\mathrm{OH})_{2} \mathrm{FA}\right]=\left[\mathrm{Ni}(\mathrm{II})_{\text {total }}\right]-\left[\mathrm{Ni}(\mathrm{II})_{\text {free }}\right]$

\begin{tabular}{|c|c|c|c|c|}
\hline \multicolumn{4}{|c|}{$\mathrm{Mol} / \mathrm{L}$} & \multirow{2}{*}{$\mathrm{F}(\mathrm{FA})$} \\
\hline$\left[\mathrm{FA}_{\text {total }}\right]$ & {$\left[\mathrm{Ni}(\mathrm{II})_{\text {total }}\right]$} & {$\left[\mathrm{Ni}(\mathrm{OH})_{2} \mathrm{FA}\right]$} & {$\left[\mathrm{FA}_{\text {free }}\right]$} & \\
\hline $4.44 \times 10^{-5}$ & $4.64 \times 10^{-5}$ & $4.26 \times 10^{-5}$ & $0.18 \times 10^{-5}$ & $6.26 \times 10^{6}$ \\
\hline $6.66 \times 10^{-5}$ & $6.64 \times 10^{-5}$ & $6.26 \times 10^{-5}$ & $0.40 \times 10^{-5}$ & $4.12 \times 10^{6}$ \\
\hline $8.88 \times 10^{-5}$ & $9.00 \times 10^{-5}$ & $8.62 \times 10^{-5}$ & $0.26 \times 10^{-5}$ & $8.72 \times 10^{6}$ \\
\hline $11.10 \times 10^{-5}$ & $11.08 \times 10^{-5}$ & $10.62 \times 10^{-5}$ & $0.48 \times 10^{-5}$ & $5.83 \times 10^{6}$ \\
\hline $13.32 \times 10^{-5}$ & $12.40 \times 10^{-5}$ & $12.02 \times 10^{-5}$ & $1.30 \times 10^{-5}$ & $2.43 \times 10^{6}$ \\
\hline $15.54 \times 10^{-5}$ & $15.68 \times 10^{-5}$ & $15.30 \times 10^{-5}$ & $0.24 \times 10^{-5}$ & $16.77 \times 10$ \\
\hline $17.76 \times 10^{-5}$ & $17.60 \times 10^{-5}$ & $17.22 \times 10^{-5}$ & $0.54 \times 10^{-5}$ & $8.40 \times 10^{6}$ \\
\hline
\end{tabular}

Table 4. The calculation of conditional stability constant of nickel fulvate complex by the least square vethod. $\mathrm{Mw}(\mathrm{FA})=1903 ; \mathrm{pH}=9.0 ; \mathrm{X}_{\mathrm{i}}=\left[\mathrm{FA}_{\text {free }}\right] ; \mathrm{Y}_{\mathrm{i}}=\mathrm{F}(\mathrm{FA})$

\begin{tabular}{cccc}
\hline $\mathrm{X}_{\mathrm{i}}$ & $\mathrm{Y}_{\mathrm{i}}$ & $\mathrm{X}_{\mathrm{i}} \mathrm{Y}_{\mathrm{i}}$ & $\mathrm{X}_{\mathrm{i}}^{2}$ \\
\hline $0.18 \times 10^{-5}$ & $6.26 \times 10^{6}$ & 11.27 & $0.0324 \times 10^{-10}$ \\
$0.40 \times 10^{-5}$ & $4.12 \times 10^{6}$ & 16.48 & $0.1600 \times 10^{-10}$ \\
$0.26 \times 10^{-5}$ & $8.72 \times 10^{6}$ & 22.672 & $0.0676 \times 10^{-10}$ \\
$0.48 \times 10^{-5}$ & $5.83 \times 10^{6}$ & 27.984 & $0.2304 \times 10^{-10}$ \\
$1.30 \times 10^{-5}$ & $2.43 \times 10^{6}$ & 31.59 & $1.6900 \times 10^{-10}$ \\
$0.24 \times 10^{-5}$ & $16.77 \times 10^{6}$ & 40.248 & $0.0576 \times 10^{-10}$ \\
$0.54 \times 10^{-5}$ & $8.40 \times 10^{6}$ & 45.36 & $0.2916 \times 10^{-10}$
\end{tabular}

In the balanced solutions, correlation $\left[\mathrm{Ni}(\mathrm{II})_{\text {total }}\right]:\left[\mathrm{FA}_{\text {total }}\right]$ on average equals to 1:0.25 (Table 1). This means that during the complex formation process, the associate of $\mathrm{FA}$, which $\mathrm{Mw}$ at $\mathrm{pH}=9.0$ equals to 7610 , divides and every 0.25 part of this associate inculcates into nickel's (II) inner coordination sphere, as an integral ligand. So it may be assumed that $\mathrm{Mw}$ of the associate of FA which takes part in the complex formation process equals to 1903. This part of the associate of FA was conventionally called the "active associate". ${ }^{43}$ The meaning of Mw of the "active associate" of FA $(\mathrm{Mw}=1903)$ was used for determining the concentration of free ligand $\left[\mathrm{FA}_{\text {free }}\right]$ and average stability constant.

For the calculation of average stability constant of nickel fulvate at $\mathrm{pH}=9.0$ was used Leden function $\mathrm{F}(\mathrm{L}) .^{44}$

$$
\begin{aligned}
& \text { Function } \left.\mathrm{F}(\mathrm{L})=\mathrm{F}(\mathrm{FA})=\left[\mathrm{Ni}(\mathrm{OH})_{2} \mathrm{FA}\right] /\left\{\left[\mathrm{Ni}(\mathrm{II})_{\text {free }}\right]\left[\mathrm{FA}_{\text {free }}\right]\right)\right\}= \\
& =\left(\left[\mathrm{Ni}(\mathrm{II})_{\text {total }}\right]-\left[\mathrm{Ni}(\mathrm{II})_{\text {free }}\right]\right) /\left(\left[\mathrm{Ni}(\mathrm{II})_{\text {free }}\right]\left[\mathrm{FA}_{\text {free }}\right]\right)=\beta_{1}+\beta_{2}\left[\mathrm{FA}_{\text {free }}\right]
\end{aligned}
$$

where

$$
\left[\mathrm{FA}_{\text {free }}\right]=\left[\mathrm{FA}_{\text {total }}\right]-\left[\mathrm{Ni}(\mathrm{OH})_{2} \mathrm{FA}\right]=\left[\mathrm{FA}_{\text {total }}\right]-\left\{\left[\mathrm{Ni}(\mathrm{II})_{\text {total }}-\mathrm{Ni}(\mathrm{II})_{\text {free }}\right]\right\}
$$


Under the solubility method, the concentration of $\left[\mathrm{Ni}(\mathrm{II})_{\text {free }}\right]$ equals to the initial concentration of metal before adding ligand in solution. It should be emphasized, using average molecular weights of "active associates" in the given systems is both real and forced, because as it is shown from data (Table 1), with the solubilty method, in any point the molar concentration of fulvate complex exceeds the molar concentration of total associate, which average molecular weight at $\mathrm{pH}=9.0$ is big enough. Therefore, free ligand cannot be calculated. Without it, it is impossible to determine the stability constant of fulvate complex.

When $\left[\mathrm{FA}_{\text {free }}\right]$ aspires to zero, $\beta$ could be found by the graphical method. The $\mathrm{m}$ section which is cut on the ordinate by the straight line built in coordinates $\mathrm{F}(\mathrm{FA})-\left[\mathrm{FA}_{\text {free }}\right]$ equals to the stability constant. The value of $\beta$ is calculated by the square method:

$$
\beta=\left(\Sigma \mathrm{y}_{\mathrm{i}}-\mathrm{a} \Sigma \mathrm{x}_{\mathrm{i}}\right) / \mathrm{n}
$$

where

$$
\begin{gathered}
\mathrm{a}=\left(\mathrm{n} \Sigma \mathrm{x}_{\mathrm{i}} \mathrm{y}_{\mathrm{i}}-\Sigma \mathrm{x}_{\mathrm{i}} \Sigma \mathrm{y}_{\mathrm{i}}\right) /\left[\left(\mathrm{n} \Sigma \mathrm{x}_{\mathrm{i}}^{2}-\left(\sum \mathrm{x}_{\mathrm{i}}\right)^{2}\right)\right] \\
\mathrm{x}_{\mathrm{i}}=\left[\mathrm{FA}_{\text {free }}\right]
\end{gathered}
$$

and

$$
\mathrm{y}_{\mathrm{i}}=\mathrm{F}(\mathrm{FA})
$$

The necessary data, for calculating the conditional stability constants of nickel dihydroxy fulvate complex are given in Tables 3 and 4 .

$$
\begin{gathered}
\beta\left(\mathrm{Ni}(\mathrm{OH})_{2} \mathrm{FA}\right)=1.07 \times 10^{7} \\
\lg \beta=7.03
\end{gathered}
$$

\section{Conclusion}

Calculations have approved that in diluted water solutions nickel dihydroxy complex $\mathrm{Ni}(\mathrm{OH})_{2}{ }^{0}$ is the dominant form at $\mathrm{pH}=9.0$. It was shown that, during the complex formation process, an associate of $\mathrm{FA}$, which $\mathrm{Mw}$ at $\mathrm{pH}=9.0$ equals to 7610 divides and every 0.25 part of this associate inculcates into nickel's inner coordination sphere, as an integral ligand. This part of the associate of FA was conventionally called the "active associate". The value of Mw of the "active associate" of FA ( $\mathrm{Mw}=1903)$ was used for determining the concentration of free ligand and average stability constant. It has shown that using average molecular weights of "active associates" in the given systems is both real and forced.

It was established, that in the $\mathrm{Ni}(\mathrm{OH})_{2}$ (solid)- $\mathrm{Ni}(\mathrm{II})$ (solution)-FA- $\mathrm{H}_{2} \mathrm{O}$ system at $\mathrm{pH}=9.0$, dominates the nickel dihydroxy fulvate complex with the structure $1: 1$, which average stability constant $\beta=1.07 \times 10^{7}, \lg \beta=7.03$.

\section{Acknowledgments}

The work was done under the support of the World Federation of Scientists and the World Laboratory. 


\section{References}

[1] Varshal, G. M. Migration forms of fulvic acids and metals in natural waters. Dissertation, Vernadsky Institute of Geochemistry and Analytical Chemistry of Russian Academy of Sciences, 1994.

[2] Dulaquas, G.; Waeles, M.; Gerringa, L. A.; Midag, R.; Rijkenberg, M.; Riso, R. G. The biogeochemistry of electroactive humic substances and its connection to iron chemistry in the North East Atlantic and the Western Mediterranean Sea. J. Geophys Res-Oceans. 2018, 123, 5481-5499.

[3] Osadchyy, V.; Nabyvanets, B.; Linnik, P.; Osadcha, N.; Nabyvanets, Y. Processes Determining Surface Water Chemistry; Springer International Publishing Switzerland, 2016.

[4] Makharadze, G. A.; Supatashvili, G. D.; Varshal, G. M. Humic acids in surface waters of Georgia. Hydrochemical Materials. 1989, 106, 22-30.

[5] Makharadze, G.; Goliadze, N.; Khaiauri, A.; Makharadze, T.; Supatashvili, G. Fulvic and humin acids in surface waters of Georgia. In High-performas Polymers for Engineering-based Composites; Apple Academic Press: Waretown, NJ USA, 2016; pp 167-179.

[6] Pisarek, I.; Glowacki, M. Quality of groundwater and aquatic humic substances from main reservoire of Ground Water No. 333. J. Ecol. Eng. 2015, 16, 46-53.

[7] Aiken, G. R.; Mcknight, D. M.; R. A. Harnish R. A. Chemical characteristics of aquatic fulvic acid isolated from Lake Fryxell, Antarctica. Anal. Chim. Acta. 1999, 395, 323-334.

[8] Kovács, K.; Gáspár, A.; Sajgó, C.; Schmitt-kopplin, P.; Tombácz, E. Comparative study on humic substances isolated in thermal groundwaters from deep aquifers below 700. Geochem. J. 2012, 46, 211-224.

[9] James, A. R.; MacCarthy, P. Statistical evaluation of the elemental composition of humic substances. Org. Geochem. 1991, 17, 635-648.

[10] Ma, P.; Allen, H. E.; Yin, Y. Characterization of isolated fractions of dissolved organic matter from natural waters and a wastewater effluent. Water Res. 2001, 35, 985-996.

[11] Bertoli, A. C.; Garcia, J. S.; Trevisan, M. G.; Ramalho, T. C.; Matheus, P.; Freitas, M. P. Interactions fulvatemetal $\left(\mathrm{Zn}^{2+}, \mathrm{Cu}^{2+}\right.$ and $\left.\mathrm{Fe}^{2+}\right)$ : Theoretical investigation of thermodynamic, structural and spectroscopic properties. BioMetals. 2016, 29, 275-285.

[12] Xu, H.; Xu, D. C.; Wang, Y. Natural indices for the chemical hardness/softness of metal cations and ligands. ACS Omega. 2017, 2, 7185-7193.

[13] Gustafsson, J. P.; Persson, I.; Oromieeh, A. G.; Van Schaik, J. W.; Sjostedt, C.; Kleia, D. B. Chromium(III) complexation to natural organic matter: Mechanisms and modeling. Environ. Sci. Technol. 2014, 48, 1753-1761.

[14] Makharadze, T.; Makharadze. G. Investigation of complex formation process of copper with macromolecular organic substances, isolated from natural water. OCP. 2020, 1, 1-5.

[15] Makharadze, G.; Makharadze, T. Method of calculation of stability constants of fulvic complexes on the example of copper. JCCE. 2014, 8, 108-111.

[16] Maccarthy, P.; O'Cinneide, S. Fulvic acids: interactions with metal ions. Eur. J. Soil Sci. 2006, 25, 429-437.

[17] DE Oliveira Vaz, D.; Fernandes, A. N.; Szpoganicz, B. Complexations of divalent metallic ions with fulvic acids. Eclet. Quim. 2018, 43, 54-58.

[18] Saldana-Robles, A.; Saldana-Robles, N.; Saldana-Robles, A. L.; Damian-Ascencio, C.; Rangel-Hernandez, V. H.; Cuerraa-SSanchez, R. Arsenic removal from aqueous solutions and the impact of humic and fulvic acids. J. Clean. Prod. 2017, 159, 425-431.

[19] Zhu, B.; Ryan, D. K. Characterizing the interaction between uranul ion and fulvic acid using regional integration analysis (RIA) and fluorescence quenching. J. Environ. Radioact. 2016, 153, 97-103.

[20] Town, R. M.; Van Leeuwen, H. P.; Buffle, J. Chemodynamics of soft nanoparticulate complexes: $\mathrm{Cu}(\mathrm{II})$ and $\mathrm{Ni}(\mathrm{II})$ complexes with FA and aquatic humic acids. Environ. Sci. Technol. 2012, 46, 10487-10498.

[21] Wang, J.; Lü, C.; He, J; Zhao, B. Binding characteristics of $\mathrm{Pb}^{2+}$ to natural fulvic acids extracted from the sediments in ake Wuliangsuhai, inner Mongolia plateau, P. R. China. Environ. Earth Sci. 2016, 75, 768-779.

[22] Moiseenko, T. I.; Diny, M. I.; Gashkina, N. A.; Kremlevaa, T. A. Occurrence forms of metals in natural waters depending on water chemistry. Water Resour. 2013, 40, 407-416.

[23] Adusei-Gyamfi, J.; Ouddane, B.; Rietveld, L; Cornard, J.; Criquet, J. Natural organic matter-cations complexation and its impact on water treatment: A critical review. Water Res. 2019, 160, 130-147.

[24] Dinh, Q. T.; Li, Z; Tran, T. A.; Wang, D.; Liang, D. Role of organic acids on the bioavailability of selenium in soil: A review. Chemosphere. 2017, 184, 618-635.

[25] Makharadze, G. A.; Supatashvili, G. D.; Varshal, G. M. The research of the forms of copper in surface waters. 
Hydrochemical Materials. 1988, 103, 3-16.

[26] Whitby, H.; Planquette, H.; Cassar, N.; Bucciarelli, E.; Osburn, C. L.; Janssen, D. J.; Jay, T.; Cullen, J. T.; González, A. G.; Völker, C.; Sarthou, G. A call for refining the role of humic-like substances in the oceanic iron cycle. Sci. Rep-UK. 2020, 10, 6144-6156.

[27] Mostofa, K. M. G.; Wu, F.; Liu, C. Q.; Vione, D.; Yoshioka, T.; Sakugawa, H.; Tanue, E. Photochemical, microbial and metal complexation behavior of fluorescent dissolved organic matter in the aquatic environments. Geochem. J. 2011, 45, 235-254.

[28] Buffle, J.; Deladoey, P.; Greter, F. L.; Haerdi, W. Study of the complex formation of Copper(II) by humic and fulvic substances. Anal. Chim. Acta. 1980, 116, 255-274.

[29] Rey-Castro, C.; Mongin, S.; Huidobro, C.; David, C.; Salvador, J.; Garces, J.; Galceran, J.; Mas, F.; Puy, J. Effective affinity distribution for the binding of metal ions to a generic fulvic acid in natural waters. Environ. Sci. Technol. 2009, 43, 7184-7191.

[30] Joris, W. J.; Van, S.; Dan, B. K.; Jon, P. G. Acid-base and copper-binding properties of three organic matter fractions isolated from a forest floor soil solution. Geochim. Cosmochim. Acta. 2010, 74, 1391-1406.

[31] Orsetti, S.; Marco-Brown, J. L.; Andrade, E. M.; Molina, F. V. Pb (II) Binding to humic substances: An equilibrium and spectroscopic study. Environ. Sci. Technol. 2013, 47, 8325-8333.

[32] Lenoir, T.; Manceau, A. Number of independent parameters in the potentiometric titration of humic substances. Langmuir. 2010, 26, 3998-4003.

[33] Cheam, V.; Gamble, D. S. Metal-fulvic acid chelation equilibrium in equeous $\mathrm{NaNO}_{3}$ solution $\mathrm{Hg}$ (II), $\mathrm{Cd}(\mathrm{II})$ and Ni(II) fulvate complexes. Can. J. Soil Sci. 1974, 54, 413-417.

[34] Goncharova, T. O.; Kolosov, I. V.; Kaplin, B. T. Hydrolysis and complexation of nickel ions in solutions of FA. Hydrochemical Materials. 1978, 71, 64-72.

[35] Kostić, I.; Anđelković, T.; Anđelković, D.; Nikolić, R.; Bojić, A.; Cvetković, T.; Nikolić, G. Interaction of cobalt (II), nickel (II) and zinc (II) with humic-like ligands studied by ESI-MS and ion-exchange method. J. Serb. Chem. Soc. 2016, 81, 255-270

[36] Mantoura, R. F. C.; Dixon, A.; Rilly, J. P. The speciation of trace metals with humic compounds in natural waters. Thalassia Jugoslavica. 1978, 14, 127-145.

[37] Makharadze, G.; Goliadze, N.; Makharadze, T.; Supatashvili1, G. The determination of aveage stability constant of Nickel-FA complex at $\mathrm{pH}=8.0$ by the solubility method. JCCE. 2014, 8, 344-348.

[38] Schnitzer, M.; Skinner, S. I. M. Stability constants of Pb, Ni, Mn, Co, Ca and Mg fulvic acid complexes. Soil Sci. 1967, 103, 247-252.

[39] Schnitzer, M.; Hansen, E. H. An evaluation of methods for the determination of stability constants of metal-fulvic acid complexes. Soil Sci. 1970, 109, 333-340.

[40] Schnitzer, M.; Kerndorff, H. Reactions of fulvic acid with metal ions. Water Air Soil Poll. 1981, 15, 97-108.

[41] Revia, R.; Makharadze, G. Cloud-point preconcentration of fulvic and humic acids. Talanta. 1999, 48, 409-413.

[42] Nazarenko, V. A.; Antonovich, V. N.; Nevskaya, E. M. The Hydrolise of Metal Ions in Diluted Solutions; Moscow, 1979; pp 190.

[43] Makharadze, G.; Supatashvili, G.; Makharadze, T. New Version of calculation of stability constant of metal-fulvate complexes on the example of zinc fulvate. Int. J. Environ. Sci. Te. 2018, 15, 2165-2168.

[44] Beck, M. T; Nagypal, I. Chemistry of Complex Equilibria; New York, 1990. 